\title{
ЕКСПОЗИЦИЙНИЙ ПРОСТІР «УКРАЇНСЬКА МОВА» У ЗАКЛАДАХ ЗАГАЛЬНОЇ СЕРЕДНЬОЇ ОСВІТИ
}

\author{
Доповідь на засіданні Президії НАПН України 17 червня 2021 р.
}

https://doi.org/10.37472/2707-305X-2021-3-1-2-9

\section{ГОРОШКІНА}

\section{Олена Миколаївна}

доктор педагогічних наук, просресор, завідувач відділу навчання української мови ma simepamypu IHcmumymy педагогіки Національної академії педагогічних наук України, м. Київ, Україна

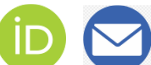

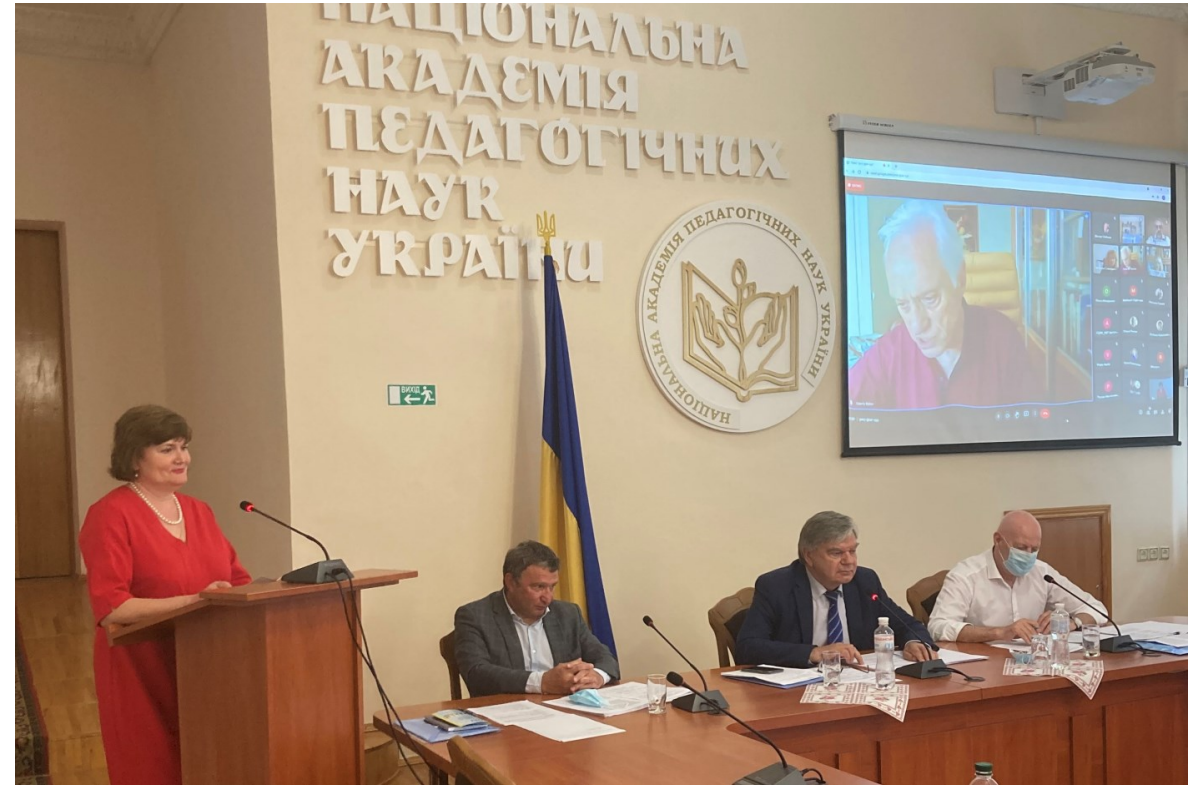

Анотація. у доповіді представлено ініціативу Уповноваженого із захисту державної мови, відділу навчання української мови та літератури Інституту педагогіки Національної академії педагогічних наук України та Педагогічного музею України щодо створення у закладах загальної середньої освіти експозиційного простору з вивчення, утвердження і популяризаиії української мови. Основними завданнями експозиційного простору є виховання в молоді патріотизму, формування активної громадянської позиції, ціннісного ставлення до української мови, історії, культури українського народу, мовної стійкості, стимулювання дослідницької діяльності здобувачів освіти тошо.

Ключові слова: українська мова; експозиційний простір; заклади загальної середньої освіти.

17 червня 2021 р. Президія НАПН України підтримала ініціативу Уповноваженого із захисту державної мови Тараса Кременя, завідувача відділу навчання української мови та літератури Інституту педагогіки НАПН України Олени Горощкіної, директора Педагогічного музею України Олександра Міхна, які розробили положення про створення у закладах загальної середньої освіти експозиційного простору з вивчення, утвердження і популяризації української мови.

Експозиційний простір «Українська мова» навчально-дослідницький та культурно-просвітницький осередок, розташований у закладі загальної середньої освіти з метою залучення учнівської молоді до утвердження, вивчення й популяризації української мови, формування в здобувачів освіти інтересу до мови та культури
України, активізації їхньої дослідницької діяльності у царині мовознавства, а також презентації досвіду вчителів-словесників.

Основні завдання експозиційного простору:

- сприяння утвердженню української мови як державної мови України;

- виховання в молоді патріотизму, формування активної громадянської позиції, ціннісного ставлення до української мови, історії, культури українського народу, мовної стійкості;

- популяризація української мови, її ролі в розвиткові української та європейської культур;

- залучення здобувачів освіти до розширення функцій української мови, збереження її чистоти;

- стимулювання пошукової, науково-дослідницької, краєзнавчої, історико-літературної діяльності здобувачів освіти; 
- вивчення, збереження й популяризація пам'яток української філології, культури рідного краю.

Основними напрямами роботи експозиційного простору визначено навчально-дослідницький, культурно-просвітницький, експозиційний.

Перший напрям передбачає:

- спрямування дослідницької уваги учнів на вивчення української мови в ії синхронічному та діахронічному аспектах;

- проведення навчально-виховних та науковопрактичних заходів;

- ознайомлення здобувачів освіти з історією розвитку української мови;

- здійснення дослідницьких проєктів (у межах освітнього процесу, у системі Малої академії наук України тощо)

Культурно-просвітницький напрям спрямований на:

- організацію різноманітних форм комунікації зустрічей, круглих столів з вченими, письменниками, громадськими діячами, проведення дискусій, тренінгів, конференцій, семінарів, презентацій тощо;

- підтримку громадських ініціатив, спрямованих на популяризацію та вивчення української мови;

- відзначення свят, зокрема Міжнародного дня рідної мови, Дня української писемності, Дня слов'янської писемності тощо, ювілейних дат українських мовознавців, письменників, громадських та культурних діячів.

Експозиційний напрям зумовлює організацію тематичних виставок.

\section{СПИСОК ВИКОРИСТАНИХ ДЖЕРЕЛ}

Закон України «Про забезпечення функиіонування української мови як державної». (2019). https:// zakon.rada.gov.ua/laws/show/2704-19

Національна академія педагогічних наук України. (2021, 17 червня). НАПН України підтримала ініціативу Уповноваженого із захисту державної мови Тараса Кременя щодо експозиційного простору "Українська мова» у закладах освіти. https://naps.gov.ua/ua/press/releases/2359/

Уповноважений із захисту державної мови. (n.d.). https://mova-ombudsman.gov.ua/

\section{THE EXHIBITION SPACE “UKRAINIAN LANGUAGE” IN GENERAL SECONDARY EDUCATION INSTITUTIONS Report at the meeting of the Presidium of the National Academy of Educational Sciences of Ukraine, June 17, 2021}

\section{Olena Goroshkina}

DSc in Pedagogy, Professor, Head of the Department of Teaching Ukrainian Language and Literature, Institute of Pedagogy of the National Academy of Educational Sciences of Ukraine, Kyiv, Ukraine

Abstract. The initiative of the State Language Protection Commissioner, Department of Teaching Ukrainian Language and Literature at the Institute of Pedagogy of the National Academy of Educational Sciences of Ukraine and Pedagogical Museum of Ukraine on the creation of the exhibition space for studying, approving, and promoting the Ukrainian language in general secondary education institutions. The main tasks of the exhibition space are the education of patriotism in youth, formation of an active civil position, valuable attitude to Ukrainian language, history and culture, language stability, promotion of students' research activities, etc.

Keywords: Ukrainian language; . exhibition space; general secondary education institutions. 